\title{
Can the Tripartite 'Driver-Car-Environment' System Save Lives?
}

\section{Introduction}

Despite varying car use levels and driving conditions, the number of accidents per 100 vehicles is not significantly different from country to country. Authorities and experts from across the world are trying to solve the problem of road safety adopting narrow professional and subjective methods (improving the intelligent systems of driving and road networks, driver training, etc.) These attempts do not affect the number of accidents but only reduce the severity of accidents by improving passive safety. Irrespective of the variety approaches to the investigation of a complex [D-C-E]-type macrosystem, the road safety problem has not been solved and remains relevant for all countries. The proclamation by the UN General Assembly of the period 2011-2020 as a decade of action to ensure road safety shows that this is a serious problem of international development, requiring to be dealt with urgency.

Ukraine has extremely low road-safety ratios, which leads to significant human and economic losses due to road fatalities and injuries. On June 22-23, 2017, the 1st International Congress on Reforming the Management System of Road Safety in Ukraine was held in Kyiv under the motto: 'Safe Roads for Life.' As noted at the Congress, fundamental shifts in the security philosophy are required to increase road-safety ratios in Ukraine and the world. This will contribute to the formulation and use of systems road-safety guidelines in the decision-making process of the Government and the public.

We still lack a methodological framework on which an effective theory and expert opinion on road-safety issues will be based. In the existing approaches and principles developed to ensure road safety, it is hard to

${ }^{1}$ Olga Goncharova, $\mathrm{PhD}$, Associate Professor, Odessa National Polytechnic University, Institute of Mechanical Engineering. 
see unanimity of views and methods applied by specialists working in this field. This is primarily due to the fact that the road-safety paradigm has not yet been adopted in the academic world. Often, road-safety researchers and developers use such poorly defined terms as 'risk' (probability theory), 'catastroph (catastrophe theory), 'reliability' (reliability theory), 'damage' and 'vulnerability', which often leads to confusion in their practical application. It is not clear what from this list (risk, catastrophe, reliability, vulnerability or damage) is the very definition of the core item of ensuring safety. All these using terms were taken from different areas of science without an integrating principle. At present, the scientific methods of inquiry based on such terminology are self-contained and methodologically poorly integrated. The mismatch of methodologies, in our opinion, is the major obstacle to the development of general principles of the theoretical basis and the elaboration of a holistic picture of road-safety.

It seems that the post-non-classic science and modern complexity theory (the concept of 'thinking in complexity') should articulate an authoritative position in this matter as it allows us to see the problem in a comprehensive manner and as an interconnection of many systems and processes. The problem of the safety of a complex macrosystem [D-C-E] has not yet been the subject of a separate, in-depth and systematic study in the context of the basic 'thinking-in-complexity' concept. The relevance of the problem combined with the inadequacy of the existing development have necessitated our research.

This article is first focused on the methodological aspects of the improvement in the safety of a complex [D-C-E]-type macrosystem from the perspective of 'thinking in complexity'.

\section{Literature Review}

There are two leading trends in the modern automobile industry as regards the improved design of vehicles and the entire [D-C-E]-type macrosystem, including to ensure its safety. Both tendencies are toward reducing the influence of the human factor. In this, the former is reflected in a decreased role of the driver in the system, in the hope that the human factor, as the main cause of the accident, would thereby be eliminated by transforming the [D-C-E]-type macrosystem into a [C-E]-type one, which excludes attention to the driver but preserves, and sometimes exacerbates, the safety problem. However, now the problem takes place at the level of another macrosystem [P - a person, not a driver] - [C-E]. On 13 March 2017, the popular American magazine Wired published an article under the paradoxical heading „To Make Us All Safer, Robocars Will Sometimes Have to Kill”. The essence of the article is that even the autopilot could not fully ensure the safety of a person, although it is expected that it will significantly increase 
the level of security. No matter how often we talk, for example, as part of the BMW's 'Alive Geometry' concept, about the self-driving car and, no matter how convincingly the slogan 'The car and the driver are companions' may sounds, one has to admit that 'The car will be the digital driver', and therefore in general algorithmic. And in that capacity it would be more appropriately classified as a 'program-driving' rather than 'self-driving' vehicle.

Program-driving cars will become safe once program-controlled pedestrians appear on the road. The number of ways to violate the traffic rules is so great that it is hardly possible to train a computer to react to them all. On the other hand, under pressure of the vehicle-to-population ratio, a significant part of drivers operate worse than the autopilot.

The second tendency does not exclude the person from the system but involves monitoring of the driver's psychophysiological state. Leading manufacturers offer a number of monitoring systems for controlling the pulse, blood pressure, emotional state, degree of fatigue and the driver's concentration on the road traffic.

There is no the unequivocal correlation between the 'grade' of vehicle automation and the number of accidents. More than 30,000 people die every year in road accidents only in the United States in conditions of well-organised traffic and quality vehicles. Worldwide, it is more than a million. Mechatronic systems significantly reduce the severity of accidents by prevention of driving errors (active safety) and weakening the traumatic effect (passive safety) but do not affect their number as such. This increases the 'rigidity' of the environment and adds to the burden on man and nature.

Another trend is the change in the traditional transport system as a whole. In 2009, the English explorers Kingsley Dennis and John Urry predicted a rapid transformation of the traditional transport system, which, in their opinion, now is in the position of 'self-organised criticality', into a 'post-car system' that has several scenarios of implementation ${ }^{2}$. Recently, entirely different post-vehicle systems, such as HYPERLOOP by Elon Musk and the Sky Way String Transport project by Anatoly Yunitskiy, have been actively developed and with them, according to experts, road safety could grow 100 times.

The evolution of the [D-C-E]-type macrosystem's complexity has passed through the following stages. At the initial stage, the car was designed as a product or as the engineering implementation of the notion of a self-propelled apparatus. With the development of mechanics, electronics and information technologies, the car is perceived as a mechatronic system (the term 'mechatronics' was introduced by Tetsuro Mori of Yaskawa Electric in 1969), the designing of which requires careful coordination of heterogeneous components that will work in aggregate. Mechatronics describes the patterns of mechanical system operations controlled by microprocessor

\footnotetext{
${ }^{2}$ К. Денніс, Д. Аррі, Після автомобілізму, Темпора, Київ 2010, passim.
} 
facilities. Further, the complicated man-machine system ${ }^{3}$, which was later expanded to a complex socio-technical systems ${ }^{4}$, becomes a subject of study and design in post-non-classic science. In its research and design, such a system should take into account factors, external to the technical system, of the social and natural environment. At the present stage, explorers consider cyber-physical systems ${ }^{5}$, through which complex socio-technical (largely self-controlled) systems could be modelled. The basis for understanding of self-organisation and emergence in such systems is the mathematical theory of complex systems and non-linear dynamics.

\section{Methodology}

Prof. Klaus Mainzer, commonly referred to as a researcher of complexity with a focus on complex systems, algorithms and artificial intelligence in science and society, emphasises that the methodology of complexity is applicable to systems of different matter, since this is an ,interdisciplinary methodology to explain the increasing complexity and differentiation of forms by phase transitions." Understanding the principles of assembling parts into a sustainable evolutionary whole, the principles of non-linear synthesis, one can choose and design a system with desired properties as an integral unity and foresee the unforeseeable, at least in engineering practice. „In engineering science, we should aim at self-organising systems with controlled emergence of new appropriate features. By detecting global trends and order parameters of complex dynamics, we have the chance of implementing favourite tendencies. By cooperation in complex systems we can make much more progress in choosing our next steps. Cooperation in complex systems supports deciding and acting for the sustainable future of a complex world"6.

This article seeks to describe the methodology of studying a complex [D-V-E]-type macrosystem in the context of the basic principles of post-non-classical science and the notion of 'thinking in complexity'. The purpose of the study is to establish that [D-C-E]-type macrosystem is a complex structure, connecting systems of different classes into a distinctive 'whole', to show its openness, self-organisation, human- and psycho-di-

${ }^{3}$ В. Стёпин, Научное познание и иенности техногенной ицвилизации, „Вопросы философии" 1989, nо 10, p. 3-18.

${ }^{4}$ В. Горохов, Эволюиия сложности технических систем [in:] Инновационная сложность, Е. Князева (ed.), Издательский дом «Алетейя», St. Petersburg, 2016, p. 446-468.

${ }^{5}$ К. Майнцер, Исследуя сложность: от искусственной жизни и искусственного интеллекта к кибербизическим системам [in:] Е. Князева (ed.), Инновационная сложность, Издательский дом «Алетейя», Санкт-Петербург 2016, р. 469-508.

${ }^{6} \mathrm{~K}$. Mainzer, Thinking in Complexity, The Computational Dynamics of Matter, Mind, and Mankind, 5th ed., New York 2007. 
mensionality, non-linearity of development and instability ${ }^{7}$. We believe that the principal cause of road accidents is not a 'human factor' (as accepted by most researchers) but a certain incompatibility between such units, connected within the [D-C-E]-type macrosystem and belonging to different classes, such as the open non-linear system (ONLS) 'Driver', the closed linear system (CLS) 'Car' and ONLS 'Environment' (1). We note the critical difference of dissimilar complex systems in the course of their interactions (2).

We introduce the concept of a new type of macrosystem, which includes the systems described below. These components of the macrosystem are characterised by structure and organisation. Systems are classified as 'simple/complex', 'open/closed', 'self-organising/non-self-organising', 'linear/ non-linear', and 'accomplished/becoming. The macrosystem itself is characterised by connections between systems/parts/elements, it has macroand micro-levels and the controlling parameter.

There are two levels in the structure of the [D-C-E]-type macrosystem: - a macro-level, at which, firstly, systems of different classes [D], [C], [E] are connected into a single [D-C-E]-type macrosystem, and, secondly, these systems of different classes are considered not within the 'partwhole' concept (or as part of one whole) but as a distinctive 'whole', included in a single [D-C-E]-type macrosystem (according to the conceptual model of psycho-synergetics, 'whole in a whole');

- a micro-level, at which exist separate systems/'whole' [D-C-E]-type macrosystem. There is a synergy of micro- and macro-levels of the [D-C-E]-type macrosystem, where the very designation of 'micro' and 'macro' becomes uncertain and conditional.

We believe that the macro-level can be regarded as a distinctive-whole system formed by the interaction of different combined systems depending on their activity rate and leading to the mobility of the control parameter's manifestation, which has not been described by anyone. The components of the macro-level in synergetics are called 'order-parameters'. The 'whole', in which the characteristics of the control/order-parameter are manifested, controls the other integral parts that constitute it. The behaviour of the [D-C-E]-type macrosystem depends on the behaviour of the connected systems, and the latter depends on the class of their components. The system class determines the specific features of the system behaviour.

When connecting systems into the [D-C-E]-type macrosystem, a mega-level appears - the 'control/order-parameter' of the connecting product of the three systems [D], [C], [E] manifests itself in the floating mode (can be any of the four systems).

${ }^{7}$ О. Гончарова, Проблемы методологии исследования человекомерных систем типа «водитель-автомобиль-среда» в контексте постнеклассики [in:] Материалы IV Всероссийской научной конферениии с международным участием «Конструирование Человека», 26-29.04.2011, p. 137-145, http://www.ipr.tomsk.narod.ru (access: 05.05.2018). 
The 'order-parameter (OP) in $\mathrm{H}$. Haken's 'synergetics' means the very slow changing 'eternal' variables of the mega-level that function as order-parameters of the underlying macro-level. By smoothly varying the OP, it is possible to change the system of the lower levels. The 'whole in a whole' concept takes account of the existing degree of their inadequacy and the possible degree of adequacy that could be obtained in the design of the car.

The degree of adequacy/inadequacy of or match/mismatch between the class of systems entering the [D-C-E]-type macrosystem becomes the criterion for estimating the critical difference/critical threshold of adequacy, and therefore for the safety/injury rate and resource-saving.

The concept of the critical threshold (I. Prigogine)/critical difference (H. Haken) represents a certain criticality as some state, a 'phase-transition' point reached by the system in its states, typified by selected indicators. The achievement of this point by the system leads to a quantum leap of the system status or behaviour, both positive and negative. In our case, this is the degree of adequacy/inadequacy of the systems [D], [C], [E].

This gave an impulse to the development of methodology for investigating the interaction of systems of different classes: firstly, a 'Driver' - an open non-linear self-organising human-dimensional system; secondly, a 'Car' - a closed linear system; and, thirdly, the 'Environment' - an open non-linear self-organising nature-dimensional system (O. Goncharova, I. Ershova-Babenko, 2009-2016). None of the general scientific methodological approaches (structural, functional, holistic, elemental, systematic, cybernetic, ecological, or synergistic) reflects the multiclass nature of assembling systems and considers them in terms of the 'whole in a whole' concept. This is the same problem of instrumentality formalisation of the [D-V-E]-type macrosystem inquiry and design.

Besides the foregoing, human- and psycho-dimensionality suggests that this environment differs from the natural one, i.e. ONLS (human-dimensional) $\neq$ ONLS (nature-dimensional). At the same time, the car (C) as an automated system, by definition, belongs to closed linear systems (CLS). As a result, a micromodel is obtained: ONLS (human-dimensional) - CLS ONLS (nature-dimensional) or [D-C-E]. The range of system differences determines the emergence of the critical threshold 1 for ONLS and CLS and the critical threshold 2 for ONLS (human-dimensional) and ONLS (nature-dimensional). This is demonstrated by a comparison of their models and principles of behaviour.

Applying the psycho-synergic conceptual model 'whole in a whole', including a 'non-linear whole in a non-linear whole' (variant: 'environment in environment'), the analysis of the behaviour of the [D-C-E]-type macrosystem is based on the premise that the conceptual model 'whole in a whole' admits the possibility of the existence of one 'whole' in the composition of another 'whole' in different modes, including a non-linear 'mac- 
ro-whole' The difference between this formulation of the problem by the newest holistic (alpha-holistic) ${ }^{8}$ and the 'new holistic' by S. Kurdyumov and co-authors $(1994)^{9}$ is that Kurdyumov's model retains the 'part-whole'-relativity, introducing a new understanding that the whole "is neither more nor less than the sum of parts, it is qualitatively different" 10 . The "whole in a whole' concept will allow to include relations in the 'non-linear whole in a non-linear whole'-mode both without influence and interaction, and with different degrees of the latter. Such a model allows us to go beyond the 'part-whole' dichotomy or reduction of the elements (reductionism), and also partly beyond the boundaries of the 'new holistic', which preserve the 'part-whole' worldview, considering "the dependence on methods with topologically correct united structures and the acceleration of the 'whole' evolution"11.

\section{Results}

The fundamental provisions for solving the complex [D-C-E]-type macrosystem safety problem have been developed within the context of the post-non-classic science principles and the 'thinking in complexity' concept.

The notion of a complex macrosystem of a new type has been introduced for the first time. It is shown that this type of macrosystems connects systems of different classes as a distinctive 'whole' on the basis of the conceptual model of the post-non-classical 'whole in a whole. The post-non-classical stage of scientific development and 'thinking in complexity' allowed to take into account the multidimensionality and multiclass nature of the systems entering the [D-C-E]-type macrosystem. An initial incompatibility of the systems was found: a 'vehicle' as a 'linear' system characterised by the 'part-whole' dichotomy; 'man' and 'environment' as open, non-linear, self-organising systems characterised by the 'whole in a whole' concept. For open, non-linear, self-organising systems (ONLS) in the post-non-classic and 'thinking in complexity' approaches, fundamentally different principles and behavioural features are shown in comparison with linear and closed ones.

It is shown that the [D-C-E]-type macrosystem is complex, characterised by openness, self-organisation, human- and psycho-dimensionality, non-linearity of development and instability. It was hypothesised that the main cause of road accidents was not a 'human factor' (as accepted by most

${ }^{8}$ И. Ершова-Бабенко, Психосинергетические стратегии человеческой деятельности. (Концептуальная модель), Nova Knyha, Вінница 2005; И. Ершова-Бабенко, Психосинергетика, Херсон: Гринь С.В. 2015, р. 432.

${ }^{9}$ Е. Князева, С. Курдюмов, Законы эволюиии и самоорганизации сложных систем, Наука, Москва 1994.

${ }^{10}$ Ibidem.

${ }^{11}$ Ibidem. 
researchers) but a certain incompatibility between such units connected within the [D-C-E]-type macrosystem and belonging to different classes as an open non-linear system (ONLS) 'Driver', a closed linear system (CLS) 'Vehicle' and ONLS 'Environment' (1) and the emergence of a 'critical difference' in the interaction of such complex systems of different classes (2).

It was shown that none of the general scientific methodological approaches (structural, functional, holistic, elemental, systematic, cybernetic, ecological, or synergistic) reflects the multiclass nature of the systems constituting the [D-C-E]-type macrosystem and considers them in terms of the 'whole in a whole' concept.

The need has been established to embrace the safety paradigm as a scientific branch on the basis of the methodology of a non-traumatic/ecological connection without combination of multiclass subsystems into a single macrosystem with a 'mega-control'. The basic idea is to take into account the 'critical difference' between a human-dimensional and/or psycho-dimensional system [D] and a system of movement, in this case a 'car', accounting for the fundamental difference in the systems entering the [D-CE]-type macrosystem.

\section{Discussion}

The main idea of this work is the study of the [D-C-E]-type macrosystem, considering the fact that it includes systems of different classes. In terms of post-non-classic science, there are: closed linear systems (vehicle); open non-linear human-dimensional (V. Stepin) ${ }^{12}$ and psycho-dimensional self-organising systems/environments (I. Ershova-Babenko); open non-linear self-organising systems (nature). The paper suggests a hypothesis about the impact of the system class on safety and the need to take into account the degree of class match/mismatch of the systems entering the [D-C-E]type macrosystem. It proposes the conceptual model of psycho-synergetics 'whole in a whole'13 as the most adequate in the methodological aspect. The 'whole in a whole' or 'environment in an environment' concept allows us to consider human- and psycho-dimensionality as a factor affecting safety, not through automation (since it adds to the burdens on man and nature) ${ }^{14}$, but through the methodological matching of the 'openness/closure' parameters of the assembling systems. This concept will also allow to take into account the existing degree of inadequacy of the systems $[D]$ and $[C]$ and

12 В. Стёпин, Теоретическое знание, Прогресс-Традиция, Москва 2000; В. Стёпин, Научное познание и иенности техногенной цивилизации, „Вопросы философии" 1989, no10, р. 3-18.

${ }^{13}$ И. Ершова-Бабенко, Психосинергетические...; И. Ершова-Бабенко, Психосинергетика..., p. 432.

${ }^{14}$ Н.Н. Талеб, Антихрупкость. Как извлечь выгоду из хаоса, Н. Караев (translation from English), М. КоЛибри, Азбука-Аттикус 2014. 
the possible degree of adequacy that can be obtained in the design of the car. In the paper, it is proposed to investigate the [D-C-E]-type macrosystem from the standpoint of the conceptual 'whole in a whole' model since it deals with the interaction of 'heterogeneous' integrities (driver, vehicle, environment). Defining the type of relationship between the integrities ('whole in a whole', 'complex in a complex'), the new quality of a 'whole' [D-C-E]-type macrosystem is determined by the nature of the communications and the emergence of a match/mismatch between different integrities.

For open, nonlinear, self-organising systems (ONLS) in the post-nonclassic approach, fundamentally different principles and behavioural features are shown in comparison with linear and closed ones.

In accordance with this idea, a new post-non-classical interpretation of a complex [D-C-E]-type macrosystem is proposed and takes the following form: $\left[\mathrm{C}^{\mathrm{fD}}-\mathrm{E}\right]$, where changes of the vehicle quality and the type of relationship within the macrosystem are implied so that they become a 'friendly interface' and the ' $\mathrm{C}^{\mathrm{fD}}$ ' component is treated as a 'vehicle, designed to fulfil the requirements of the 'driver's' human- and psycho-dimensionality with the advantages and weaknesses of the latter. Then, by regulating the degree of matching (critical difference), one can influence safety in a fundamentally new way - by approximating the consistency of system behaviour in terms of 'openness/closure', 'linearity/non-linearity', and the assembly of the parts. Traditionally, the design is aimed at creating an automated system [C-E] (3), which excludes attention to the person, but preserves, and sometimes exacerbates, the safety problem.

We propose to use the post-non-classical conceptual model of a 'non-linear whole in a non-linear whole' by prof. I. Ershova-Babenko ${ }^{15}$, in which both non-linear 'wholes' and their combinations and the hyper-system can become and become a mega-level that fulfils the function of the 'control parameter' of hyper-slow variables according to H. Haken. In the post-non-classical conceptual model the notion of a 'floating' regime of the 'control parameter' was introduced to emphasise that the evidence of this parameter and its 'perceptibility' are not continuously fixed, although they can be detected by changing the scale of the examination and reaching an adequate scale.

\section{Conclusion}

The results of our research suggest that the [D-C-E]-type macrosystem is an open, complex, non-linear, unstable system in which self-organisation processes occur. To ensure the safety of the [D-C-E]-type macro system, it is necessary to take into account the role of post-non-classical macro- and

${ }^{15}$ И. Ершова-Бабенко, Психосинергетические...; И. Ершова-Бабенко, Психосинергетика..., p.432. 
mega-modelling in the presentation of the familiar 'driver-vehicle-environment' [D-C-E] system from the current scientific positions in the aspect of the 'whole in a whole' concept. In addition, one should take cognisance of the new interpretation of the macrosystem 'integrity' through the multidimensionality and inherent conflict of its constituent components. As a result, we obtain an (Open-Closed-Open)-macromodel, in which openness, self-development and self-organisation prevail. With the exclusion of the human, this prevalence is lost. Formally, there is an equilibrium in which there is no human. Nature and machines coexist perfectly, but this is another civilisation.

\section{Recommendations}

A new $\left[\mathrm{C}^{\mathrm{fD}}-\mathrm{E}\right]$-type macrosystem will ensure and improve the level of safety for drivers by:

1) reducing the 'critical difference' due to the rate of class match/mismatch of the systems combined into a macrosystem;

2) bringing the organisation level of the macrosystem closer to the characteristics of human psycho-dimensionality since this will ensure its safety as well as allow maximum intensification of human-dimensional and transport processes by using their natural capabilities in accordance with the methodology of psycho-synergetics and post-non-classics;

3) adapting resource-saving technologies, for example, the type of Sky Way String Transport concept (levels of energy, ecology, information, comfort, etc.);

4) taking into account not only the advantages but also the 'weakness' of this 'dimensionality', which is also included within the indicator called the 'degree of matching between systems assembled to a $\left[\mathrm{C}^{\mathrm{fD}}-\mathrm{E}\right]$-type macrosystem ${ }^{16}$.

\section{Bibliography}

Аршинов В., Сложность постнеклассических практик и будущее конвергирующих технологий [in:] В. Аршинов, О.Н. Астафьева (ed.), Постнеклассические практики: опыт кониептуализации: коллективная монограбия, Міръ, Санкт Петербург 2012, p. 164-188.

Гончарова О., Проблемы методологии исследования человекомерных систем типа «водитель-автомобиль-среда» в контексте постнеклассики [in:] Материалы IV Всероссийской научной конференции с международным

${ }^{16}$ О. Гончарова, Проблемы методологии исследования человекомерных систем типа «водитель-автомобиль-среда» в контексте постнеклассики [in:] Материалы IV Всероссийской научной конференции с международным участием «Конструирование Человека», 26-29.04.2011, p. 137-145, http://www.ipr.tomsk. narod.ru (access: 05.05.2018). 
участием «Конструирование Человека», 26-29.04.2011, p. 137-145, http:// www.ipr.tomsk.narod.ru (access: 05.05.2018).

Горохов В., Эволюиия сложности технических систем [in:] Е. Князева (ed.), Инновационная сложность, Издательский дом «Алетейя», Санкт-Петербург 2016, р. 446-468.

Данилов Ю. и Кадомцев Б., Что такое синергетика? [in:] сб. «Нелинейные волны. Самоорганизация», Наука, Москва 1983, р. 30-43.

Денніс К., Аррі Д., Після автомобілізму,Темпора, Київ 2010.

Ершова-Бабенко И., Психосинергетические стратегии человеческой деятельности. (Концептуальная модель), Nova Knyha, Вінница 2005.

Ершова-Бабенко И., Психосинергетика, Херсон: Гринь С.В., 2015.

Князева Е., Курдюмов С., Законь эволюиии и самоорганизации сложных систем, Наука, Москва 1994.

Ласло Э., Макросдвиг: К устойчивости мира курсом перемен, Москва 2004.

Лени Х., Социальная ответственность человека за надежность сложных социотехнических систем [in:] В. Аршинов (еd.), Синергетическая парадигма: Синергетика инновационной сложности, Прогресс-Традиция, Москва 2011, р. 237-238.

Майнцер К., Исследуя сложность: от искусственной жизни и искусственного интеллекта к кибербизическим системам [in:] Е. Князева (ed.), Инновационная сложность, Издательский дом «Алетейя», Санкт-Петербург, 2016, p. 469-508.

Морен Э., Метод. Природа Природьь, «Канон+» РООИ «Реабилитация», Москва 2013.

Николис Г. и Пригожин И., Познание сложного. Введение, В.Ф. Пастушенко (translate form English), Изд-во «Мир», Москва 1990.

Пригожин И., От существующего к возникающему: время и сложность в физических науках, Наука, Москва 1985.

Пригожин И., Философия нестабильности, „Вопросы философии” 1991, no 6, p. 46-57.

Стёпин В., Теоретическое знание, Прогресс-Традиция, Москва 2000.

Стёпин В., Научное познание и ценности техногенной цивилизации, „Вопросы философии" 1989, no10, p. 3-18.

Талеб Н.Н., Антихрупкость. Как извлечь выггоу из хаоса, translation from English Н. Караев, М. КоЛибри, Азбука-Аттикус 2014.

Хакен Г., Инбормация и самоорганизация: макроскопический поход к сложным явлениям, Мир, Москва 1991.

Goncharova O., Space-Temporal Axial Centering Conception in the 'Geometries' of Car and Driver/Person [in:] 14th International Conference on Geometry and Graphics (ICGG) "Applied Geometry and Graphics", Kyoto 2010, p. 370-371.

Haken H., Synergetics. An Introduction [in:] Nonequilibrium Phase Transitions in Physics, Chemistry and Biology, 3., erw. Aufl., Springer, Berlin 1983.

Prigogine I., Stengers I., Order out of Chaos. Man's new dialogue with nature, Heinemann, London 1984.

Mainzer K., Thinking in Complexity, The Computational Dynamics of Matter, Mind, and Mankind, $5^{\text {th }}$ ed., New York 2007. 
The aim of the work is to investigate the possibility of a non-traumatic connection of systems belonging to different classes: 'Driver/person' [D], 'Car' [C] and 'Environment' $[\mathrm{E}]$ into a single macrosystem called 'Driver/person-Car-Environment' [D-C-E] for the purposes of ensuring road safety. The key aspects of the road-safety problem in the case of the complex 'Driver-Car-Environment' [D-C-E] system are considered in the context of the basic principles of post-non-classics and 'thinking in complexity'. For the first time ever, the concept of a complex macrosystem of a new type is introduced, connecting systems of different classes into an independent 'whole' on the basis of the conceptual model of the post-non-classical 'whole in a whole'; it is hypothesised that the main cause of accidents is a certain incompatibility within the [D-C-E] macrosystem of the systems [D], [C] and [E] connected within it in terms of their membership in different classes (1), which causes the emergence of a critical difference/critical threshold for the interaction of complex systems of different classes (2). The increase in the number of road traffic accidents is due to the interaction of the 'different-quality' systems $[D],[C],[E]$ within a single macrosystem; the new quality of the macrosystem [D-C-E] is determined by the nature of the bonds and the emergence of consistency or mismatch between different integral elements in a single macrosystem. The need has been established to embrace the safety paradigm as a scientific branch on the basis of the methodology of a non-traumatic/ecological connection without combination of multiclass subsystems into a single macrosystem with a mega-control.

Keywords: driver, car, environment, 'whole in a whole', safety paradigm, thinking in complexity, openness, non-linearity, self-organisation, human-dimensionality, order parameters, critical difference/critical threshold

\section{Czy obejmujący trzy elementy system „Kierowca - Samochód - Środowisko” może ratować życie?}

Streszczenie

Celem artykułu jest zbadanie możliwości nietraumatycznego połączenia systemów różnych klas „kierowca/osoba” [K], „samochód” [S], „środowisko” [Ś] w jeden makrosystem „kierowca/osoba - samochód - środowisko” [K-S-Ś] dla zwiększenia bezpieczeństwa na drodze. Dokonano w nim analizy kluczowych problemów związanych z bezpieczeństwem na drodze w ujęciu kompleksowego systemu „kierowca - samochód - środowisko" [K-S-Ś] przeprowadzonej w kontekście podstawowych zasad postnieklasycyzmu oraz „myślenia w złożoności”. Po raz pierwszy wprowadzono złożony makrosystem nowego typu, wiążący systemy różnych klas w niezależną „całość” w oparciu o konceptualny model „całości w całości”. Hipoteza zakłada, iż główną przyczyną wypadków jest pewna niekompatybilność makrosystemu [K-S-Ś] systemów $[\mathrm{K}],[\mathrm{S}],[\hat{S}]$ powiązanych $\mathrm{w}$ nim z powodu ich przynależności do różnych klas (1), co prowadzi do wystąpienia krytycznej różnicy / krytycznego progu interakcji złożonych systemów należących do różnych klas (2). Za zwiększoną liczbę wypadków drogowych odpowiada współdziałanie systemów „różnej jakości” $[\mathrm{K}],[\mathrm{S}],[\hat{S}]$ w ramach pojedynczego makrosystemu. Nową jakość makrosystemu [K-S-Ś] determinuje charakter powiązań oraz pojawienie się spójności lub niedopasowania pomiędzy różnymi całościami w ramach jednego makrosystemu. Na podstawie metodologii 
bazującej na paradygmacie bezpieczeństwa stwierdzono konieczność rozwijania jako dziedziny nauki nietraumatycznego i ekologicznego powiązania podsystemów obejmujących wiele klas w jeden makrosystem z potężnym mechanizmem kontroli, jednak bez ich łączenia.

Słowa kluczowe: kierowca, samochód, środowisko, „całość w całości”, paradygmat bezpieczeństwa, myślenie w złożoności, otwartość, nieliniowość, samoorganizacja, wymiar ludzki, parametry zamówienia, krytyczna różnica/próg krytyczny 